\title{
Taxonomy and evolutionary relationships of Passiflora subg. Decaloba supersect. Decaloba sect. Xerogona (Passifloraceae): contributions of palynological, morphological and molecular studies
}

Michaele Alvim Milward-de-Azevedo ${ }^{1,4}$, Loreta Brandão de Freitas ${ }^{2}$ and Luiza Sumiko Kinoshita ${ }^{3}$

Received: April 29, 2013. Accepted: November 25, 2013

\begin{abstract}
Passiflora subg. Decaloba supersect. Decaloba sect. Xerogona (Passifloraceae) is a tropical and subtropical group comprising 14 species that occur in tropical biomes throughout Latin America, including the Atlantic Forest. The section Xerogona comprises herbaceous vines characterized by a lack of petiole glands on their leaves, of bracts and of ocelli on their leaf blades, as well as by their capsular fruits. We analyzed the phylogeny on the basis of morphological characters (including pollen characters) and molecular data. The inferred phylogeny was used in order to characterize, circumscribe and delimit the section and the species. We examined the phylogenetic relationships among the species, evaluating the circumscription of the section on the basis of the trnL-trnF intergenic spacer region of chloroplast DNA and the internal transcribed spacer region of nuclear ribosomal DNA. We constructed phylogenetic trees on the basis of the morphological and molecular data. We found that $P$. subg. Decaloba supersect. Decaloba sect. Xerogona appears to be monophyletic only in the molecular analyses. The phylogenetic analyses performed here also indicated that $P$. subg. Decaloba is monophyletic.
\end{abstract}

Key words: Passiflora, Decaloba, Xerogona, phylogenetics

\section{Introduction}

Passiflora L. subg. Decaloba (DC.) Reich. supersect. Decaloba (DC.) MacDougal \& Feuillet sect. Xerogona (Raf.) Killip (Passifloraceae) is a tropical and subtropical section comprising 14 species (Feuillet \& MacDougal 2003) that occur throughout Latin America, principally in Central America but also in other tropical regions and in the Atlantic Forest Biome. The section is characterized by the absence of ocelli on the leaf blades, by the absence of bracts, and by capsular fruits. The species are herbaceous vines with linear-subulate stipules, small flowers $(<4 \mathrm{~cm}$ diameter) with one or two series of corolla filaments, a folded operculum, and transversally sulcate seeds.

Presting (1965) initiated palynological studies of Passifloraceae and proposed a phylogeny for the family based on the pollen characters and on the classification of Killip (1938). Milward-de-Azevedo et al. $(2004,2010)$ presented a palynotaxonomic study of the species of Passiflora subg. Decaloba that contributed to their characterization and cir- cumscription, as well as to delimiting the genus Passiflora in accordance with the classification of MacDougal \& Feuillet (2004); pollen characters were found to be informative for the phylogeny of the group in both works. A cladistic analysis of morphological characters, undertaken by Milward-deAzevedo (2007) to revise P. subg. Decaloba in Brazil, did not, however, support the classification proposed by Feuillet \& MacDougal (2003), because the authors found that $P$. subg. Decaloba supersect. Decaloba included species from other supersections and therefore was not monophyletic. The evolutionary relationships of the species of $P$. subg. Decaloba supersect. Decaloba sect. Xerogona (P. capsularis L., P. cervii Milward-de-Azevedo and P. rubra L.) have not been well resolved due to their great morphological similarities and to the difficulties encountered in identifying them in their vegetative states, and the section is therefore considered a polytomy (Milward-de-Azevedo 2007).

Recent phylogenetic studies of Passiflora (Muschner et al. 2003, Yockteng \& Nadot 2004, Souza-Chies et al. 2005, Hansen et al. 2006, 2007) have not supported the

\footnotetext{
${ }^{1}$ Universidade Federal Rural do Rio de Janeiro, Instituto de Três Rios, Departamento de Ciências Administrativas e do Ambiente, Três Rios, RJ, Brazil

${ }^{2}$ Universidade Federal do Rio Grande do Sul, Departamento de Genética, Porto Alegre, RS, Brazil

${ }^{3}$ Universidade Estadual de Campinas, Instituto de Biologia, Departamento de Biologia Vegetal, Campinas, SP, Brazil

${ }^{4}$ Author for correspondence: michaelemilward@gmail.com
} 
supersectional, sectional, and series classifications within P. subg. Decaloba proposed by Reichenbach (1828). Some of the species within this group are associated with each other in complexes in which individual species are difficult to identify because of the blurring of interspecific distinctions and the existence of individuals with intermediate morphological characteristics. In view of these facts, we performed phylogenetic analyses based on morphological and molecular data in order to help clarify the taxonomy of $P$. subg. Decaloba supersect. Decaloba sect. Xerogona, as well as evaluating the circumscription of this section.

\section{Material and methods}

We selected 43 vegetative and reproductive morphological characters (Tab. 1) to be scored in a data matrix for computer analysis (Tab. 2). The selection of morphological characters concentrated on those considered relevant to the taxonomy of species of Passiflora subg. Decaloba supersect. Decaloba sect. Xerogona. Autapomorphies were not utilized, because they were not informative in establishing interspecific relationships and groupings. The characters were given equal weights and were encoded.

We performed molecular analyses of the DNA sequences of 20 species of Passiflora subg. Decaloba, nine of them belonging to $P$. subg. Decaloba supersect. Decaloba sect. Xerogona. The samples were derived from collections of young leaves dehydrated in silica gel, available in the Molecular Evolution Laboratory at the Federal University of Rio Grande do Sul, or from herbarium material. The samples were pulverized in liquid nitrogen and stored at $-20^{\circ} \mathrm{C}$. Voucher specimens were deposited in the Herbarium of the (São Paulo) State University at Campinas (code, UEC) and the Herbarium of the Federal University of Espírito Santo (code, VIES).

We extracted DNA using the method described by Roy et al. (1992). The extraction products were confirmed by electrophoresis on a $1 \%$ agarose gel, stained with ethidium bromide, and visualized using an ultraviolet transilluminator. Each sample was quantified by comparisons with markers of molecular weight and concentration (Low DNA Mass Ladder; Invitrogen, Carlsbad, CA, USA).

To amplify the samples, we performed polymerase chain reaction in automated thermal cyclers (PTC-200; MJ Research Inc., Foster City, California, USA-Mastercycler; Eppendorf, Hauppauge, NY, USA), using universal ( $c$ and $f$ ) primers for the trnL-trnF intergenic spacer region of chloroplast DNA (Taberlet et al. 1991) and internal transcribed spacer (ITS) primers 92 and 75, as described by Desfeux \& Lejeune (1996). Before sequencing, the samples were purified using the protocol described by Dunn \& Blattner (1987). The sequencing of the DNA fragments was performed in a automated sequencer (MegaBACE 1000; Amersham Biosciences/GE Healthcare, Piscataway, NJ, USA) in accordance with the manufacturer instructions, and the DYEnamic ${ }^{\mathrm{TM}}$
Table 1. Key to the morphological characters used in the cladistic analyses of Passiflora subg. Decaloba supersect. Decaloba sect. Xerogona and their respective states.

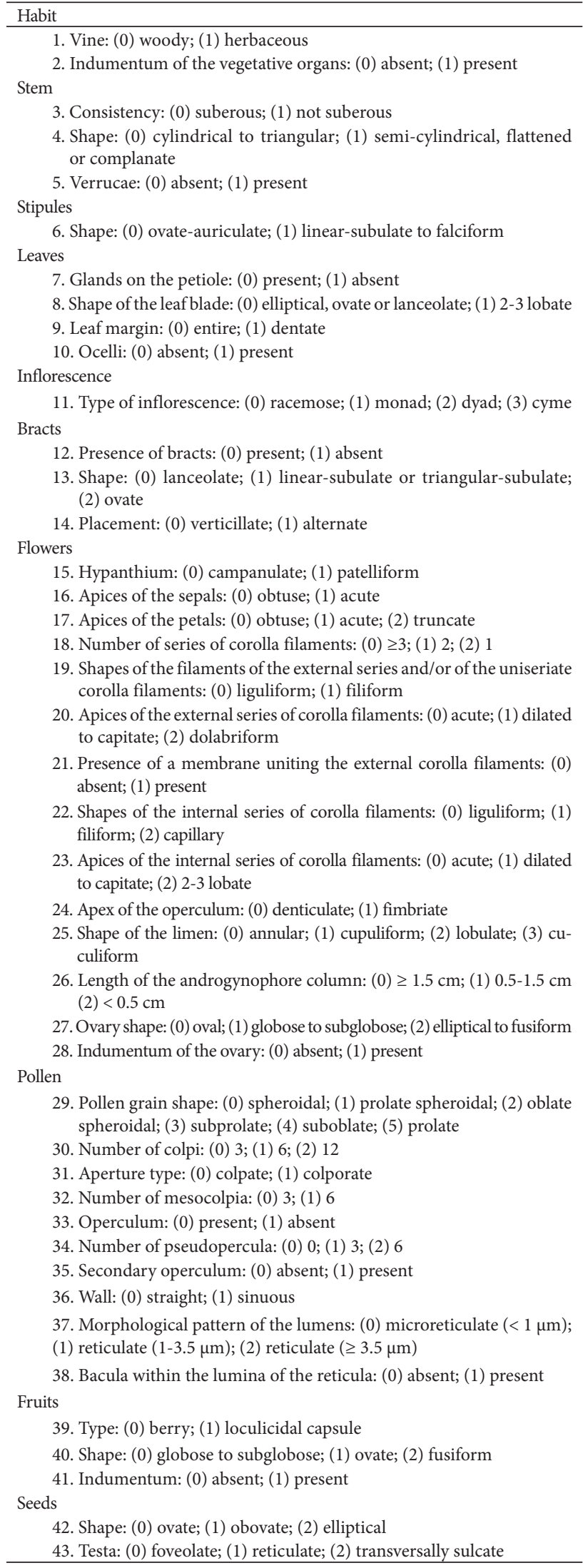


Taxonomy and evolutionary relationships of Passiflora subg. Decaloba supersect. Decaloba sect. Xerogona (Passifloraceae): contributions of palynological, morphological and molecular studies

Table 2. Character matrix for the cladistic analysis of Passiflora subg. Decaloba supersect. Decaloba sect. Xerogona, showing the states of the characters.*

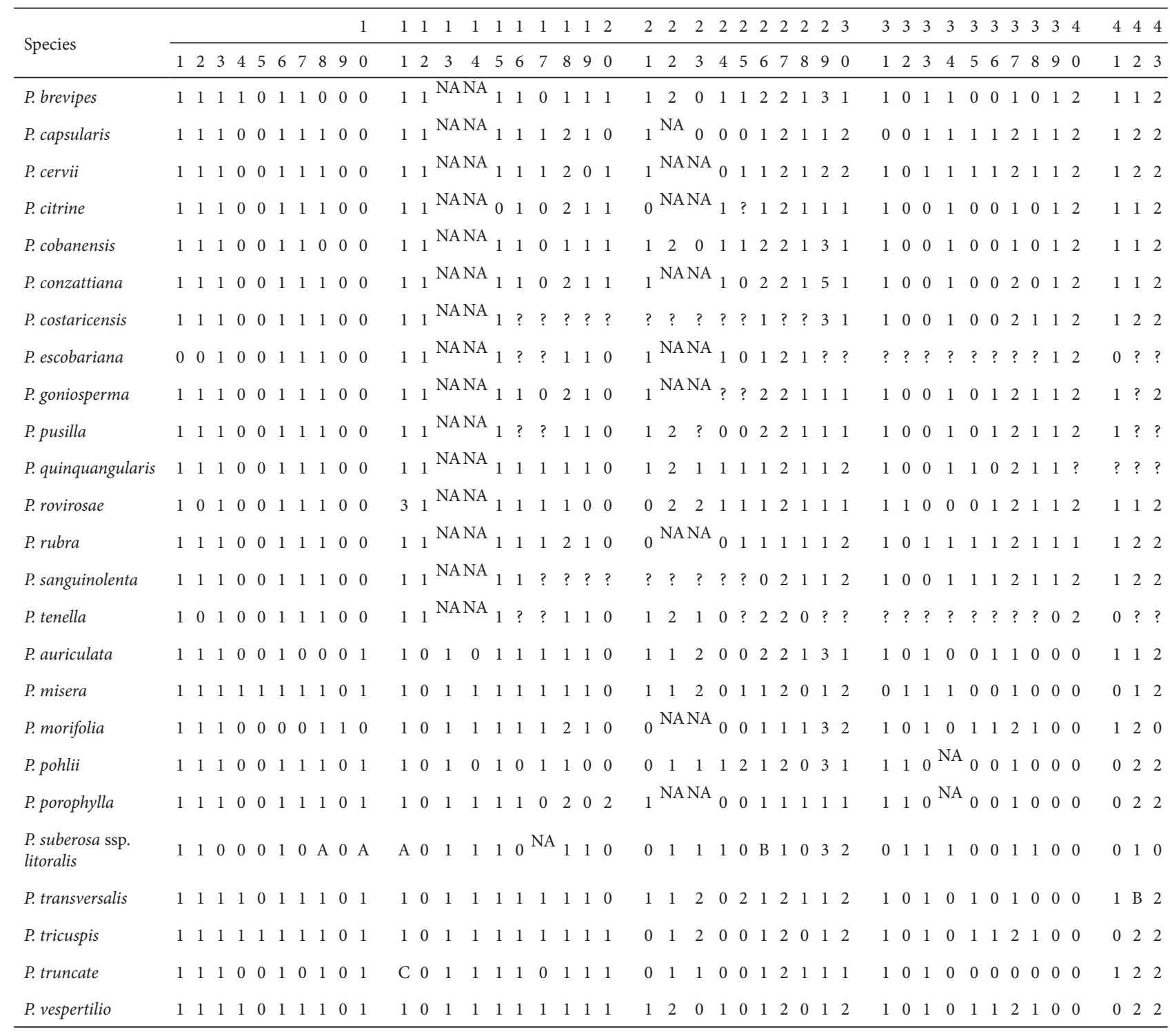

? - no data; NA - data not applicable.

${ }^{*}$ Multistate characters are indicated by individual upper-case letters: A - $(0,1) ; \mathrm{B}-(1,2) ; \mathrm{C}-(1,2,3)$.

ET terminator sequencing premix kit, with terminal fluorescent markers (Amersham Biosciences/GE Healthcare).

The data for phylogenetic analyses were organized based on morphological data and the ITS and trnL-trnF DNA sequences. We also included ITS and trnL-trnF sequences deposited in GenBank (Tab. 3). The molecular analyses used the sequences of Passiflora edulis Sims, P. haematostigma Mart. ex Mast. and P. ovalis Vell. ex M. Roem. as external groups. Sequences were visualized with the software Chromas, version 2.0 (Technelysium Pty Ltd., Helensvale, Australia), and alignments were performed with the program MEGA, version 5.01 (Tamura et al. 2011), visual adjustments being made as necessary.

Morphological and molecular phylogenetic analyses were conducted using the parsimony method in the PAUP* program, version 4.0 for Windows (Swofford, 2002). We performed heuristic searches, with the stepwise addition of taxa. For branch rearrangements, we used tree bisection and reconnection. One thousand bootstrap replications were made for each analysis. We performed morphological and molecular phylogenetic analyses with Bayesian interference using the MrBayes program, version 3.0b4 (Ronquist \& Huelsenbeck 2003), employing the evolutive models estimated in the jModeltest program, version 0.1.1 (Posada 2008). The models were obtained with the Bayesian information criterion. WE conducted four Markov chain Monte Carlo runs, with 10 million generations in each analysis. The trees were sampled after every 100 generations, and the numbers of generations necessary for each parameter to become stable (i.e., to complete the burn-in period) were 
Table 3. Accession numbers of the sequences obtained from GenBank.

\begin{tabular}{lcc}
\hline Species & ITS & trnL-trnF \\
\hline Passiflora auriculata & - & HQ901003.1 \\
P. misera & EU258409.1 & AY032777.1 \\
P. morifolia & EU258323.1 & AY032780.1 \\
P. pohlii & EU258325.1 & AY032778.1 \\
P. porophylla & EU258425.1 & AY032779.1 \\
P. suberosa ssp. litoralis & - & AY032774.1 \\
P. tricuspis & EU258459.1 & AY102396.1 \\
P. edulis & EU258383.1 & AY032769.1 \\
P. haematostigma & EU258407.1 & AY032773.1 \\
P. ovalis & EU258369.1 & AY210978.1 \\
\hline
\end{tabular}

ITS - (sequences of the) internal transcribed spacer region of nuclear of ribosomal DNA; $\operatorname{trnL}-\operatorname{trnF}$ - (sequences of the) $\operatorname{trnL}$ - $\operatorname{trnF}$ intergenic spacer region of chloroplast DNA.

defined after inspection of the log-likelihood values corresponding to those generations using the MrBayes program, with posterior probability being determined for each node. Combined analyses (of morphological and molecular data) were not within the scope of this paper, because not all species were subject to molecular analyses.

\section{Results}

\section{Morphological data}

Heuristic searches in PAUP* generated the 14 most parsimonious trees with similar topologies. The analysis was based on a consensus tree of parsimony heuristic search (Fig. 1A). Initially, the clades formed by the external groups and by Passiflora subg. Decaloba were recognized. The latter comprises two distinct clades, the first comprising $P$. subg. Decaloba supersect. Decaloba sect. Xerogona and the second comprising $P$. subg. Decaloba supersect. Decaloba sect. Decaloba and P. subg. Decaloba supersect. Cieca; and the second comprising $P$. subg. Decaloba supersect. Auriculata and P. subg. Decaloba supersect. Truncata (Fig. 1). P. subg. Decaloba supersect. Decaloba sect. Xerogona appears as monophyletic, although there is no statistical support for that. Morphologically, the most basal clade of the section appears to be composed of a complex of the species $P$. capsularis, P. cervii and P. rubra, which are quite similar species and difficult to distinguish from each other. The species $P$. quinquangularis and $P$. sanguinolenta did not demonstrate variability among the characters evaluated; nor did they demonstrate a significant quantity of synapomorphies in relation to the other species in the section, although these two species can be differentiated by the colors of their flowers (white and pink, respectively), as well as their distinct geographic distributions (Guatemala-El Salvador and Ecuador, respectively). Passiflora sanguinolenta is the only species of $P$. subg. Decaloba that has a floral tube and is adapted to pollination by hummingbirds, and the structures of the filaments of its corolla are organized for this type of pollination (Ulmer \& MacDougal, 2004). The clade formed by the species $P$. escobariana and $P$. tenella appears to be a sister group to the species $P$. rovirosae, although the last species is taxonomically distinguishable by the shape of its leaves. Passiflora tenella appears inserted within the clade of the section Xerogona (because it has a capsule fruit), although it is quite similar to the species of $P$. subg. Decaloba supersect. Decaloba sect. Decaloba. The clade composed of the species $P$. brevipes and $P$. cobanensis showed a reversion of the lobate character of the leaves to entire leaves; these species are morphologically quite similar, and there are no diagnostic characters that definitively separate them.

The consensus tree obtained by Bayesian inference (Fig. 1B) demonstrated a topology similar to that seen in the parsimony tree for Passiflora subg. Decaloba supersect. Decaloba sect. Xerogona. In this analysis, the most basal clade of the section is composed of the species $P$. capsularis, $P$. cervii, $P$. rubra and $P$. morifolia, the last being representative of $P$. subg. Decaloba supersect. Bryonioides. It can be assumed that the phylogenetic relationships between $P$. morifolia and the other species of $P$. subg. Decaloba supersect. Decaloba sect. Xerogona in this clade are supported not only by a uniseriate corolla, by pollen grains with sinuous muri and by the absence of ocelli (all of which are synapomorphies) but also by the fact that all have pollen grains with 3 mesocolpia, 3 pseudopercula and 6 secondary opercula.

In the trees obtained using these two methods of analysis based on morphological characters (Fig. 1), it can be seen that Passiflora subg. Decaloba supersect. Decaloba sect. Xerogona is divided into two large groups: a more basal group composed of the species $P$. capsularis, $P$. cervii and $P$. rubra; and another group composed of the remaining species.

\section{Molecular data}

Among the species of Passiflora subg. Decaloba supersect. Decaloba sect. Xerogona, we sequenced nine for the ITS marker and seven for the trnL-trnF marker. Sequences of 10 species representing $P$. subg. Decaloba and three species representing the other subgenera used as the external group were obtained from GenBank (Tab. 3) and included in the analyses. The markers were analyzed individually. As was expected, the amplified ITS fragments were 401-468 base pairs in size, while the trnL-trnF sequences were 199-210 base pairs.

In all of the phylogenetic analyses undertaken using the ITS and trnL-trnF markers, Passiflora subg. Decaloba was found to be monophyletic, with high statistical support (Fig. 2 and 3), as was P. subg. Decaloba supersect. Decaloba sect. Xerogona, albeit with low statistical sup- 
Taxonomy and evolutionary relationships of Passiflora subg. Decaloba supersect. Decaloba sect. Xerogona (Passifloraceae): contributions of palynological, morphological and molecular studies

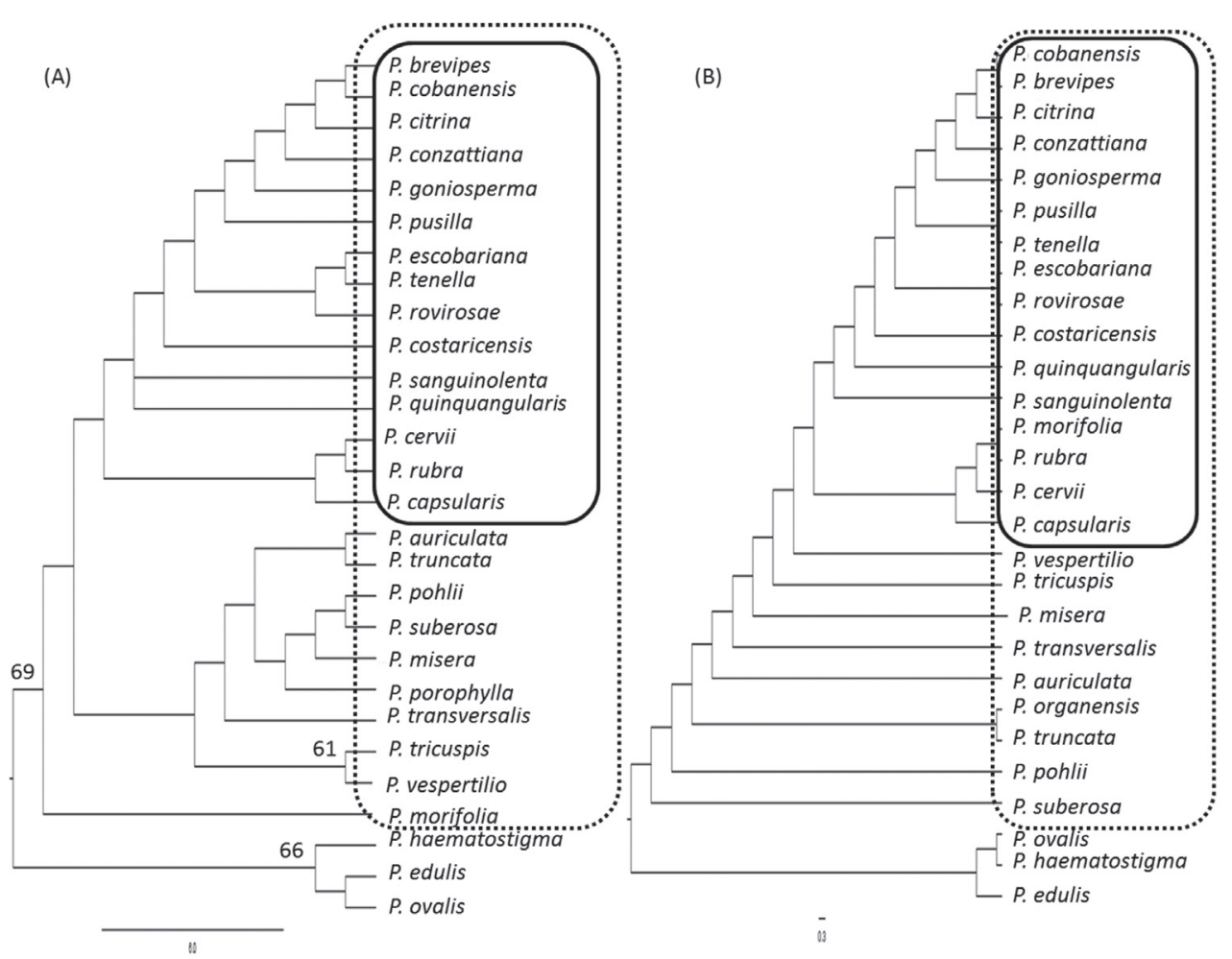

Figure 1. (A) Strict consensus tree of the 14 most parsimonious trees, based on morphological data. Numbers above branches (when higher than 50\%) are bootstrap support values based on 1000 replicates. (B) Phylogenetic tree based on morphological data obtained from Bayesian inference.

Continuous line: Passiflora subg. Decaloba supersect. Decaloba sect. Xerogona; dotted line: Passiflora subg. Decaloba.
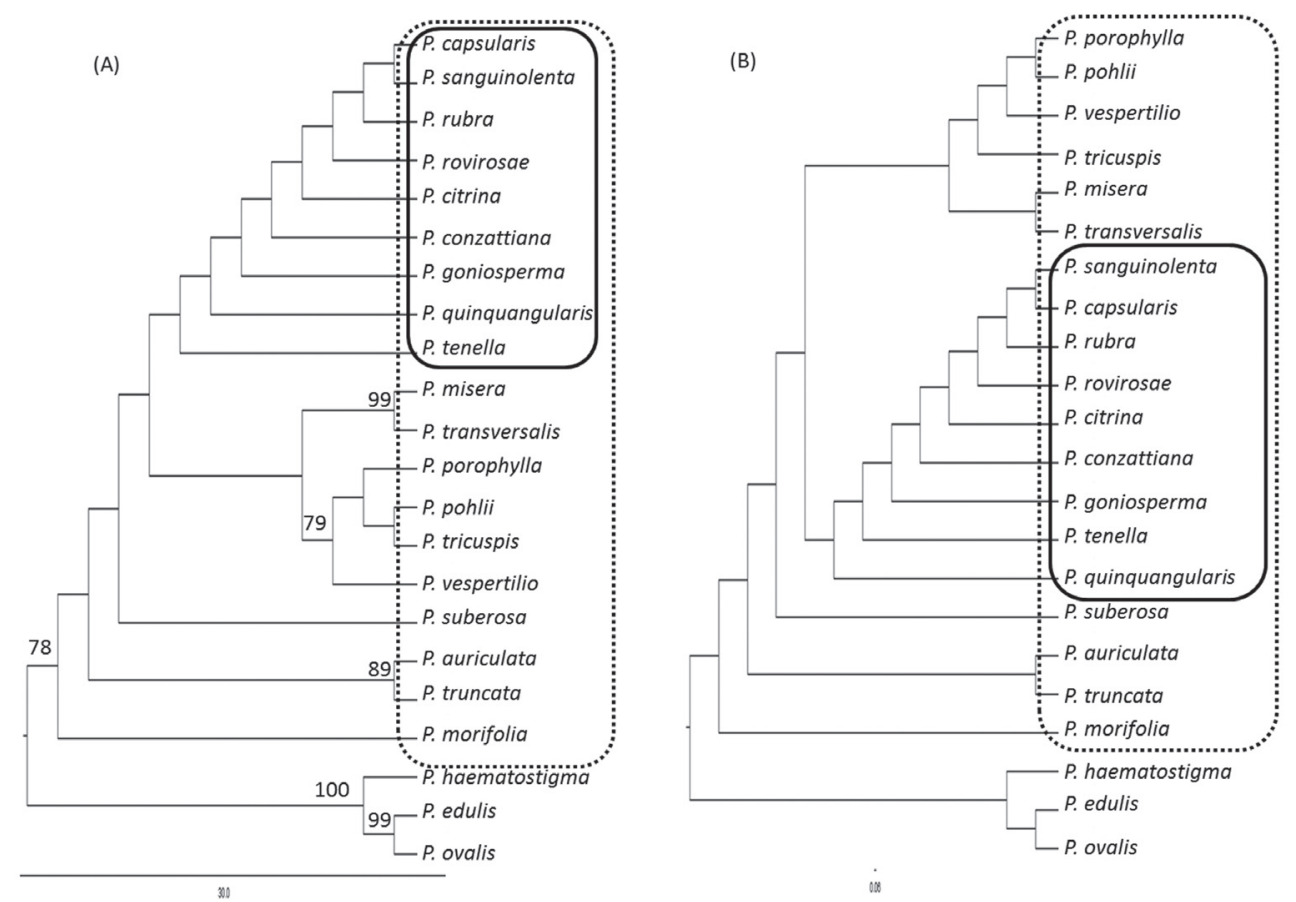

Figure 2. (A) Strict consensus tree of the 75 most parsimonious trees, constructed with the ITS marker. Numbers above branches (when higher than $50 \%$ ) are bootstrap support values based on 1000 replicates. (B) Phylogenetic tree based on the sequences of the ITS marker obtained by Bayesian inference.

Continuous line: Passiflora subg. Decaloba supersect. Decaloba sect. Xerogona; dotted line: Passiflora subg. Decaloba. 

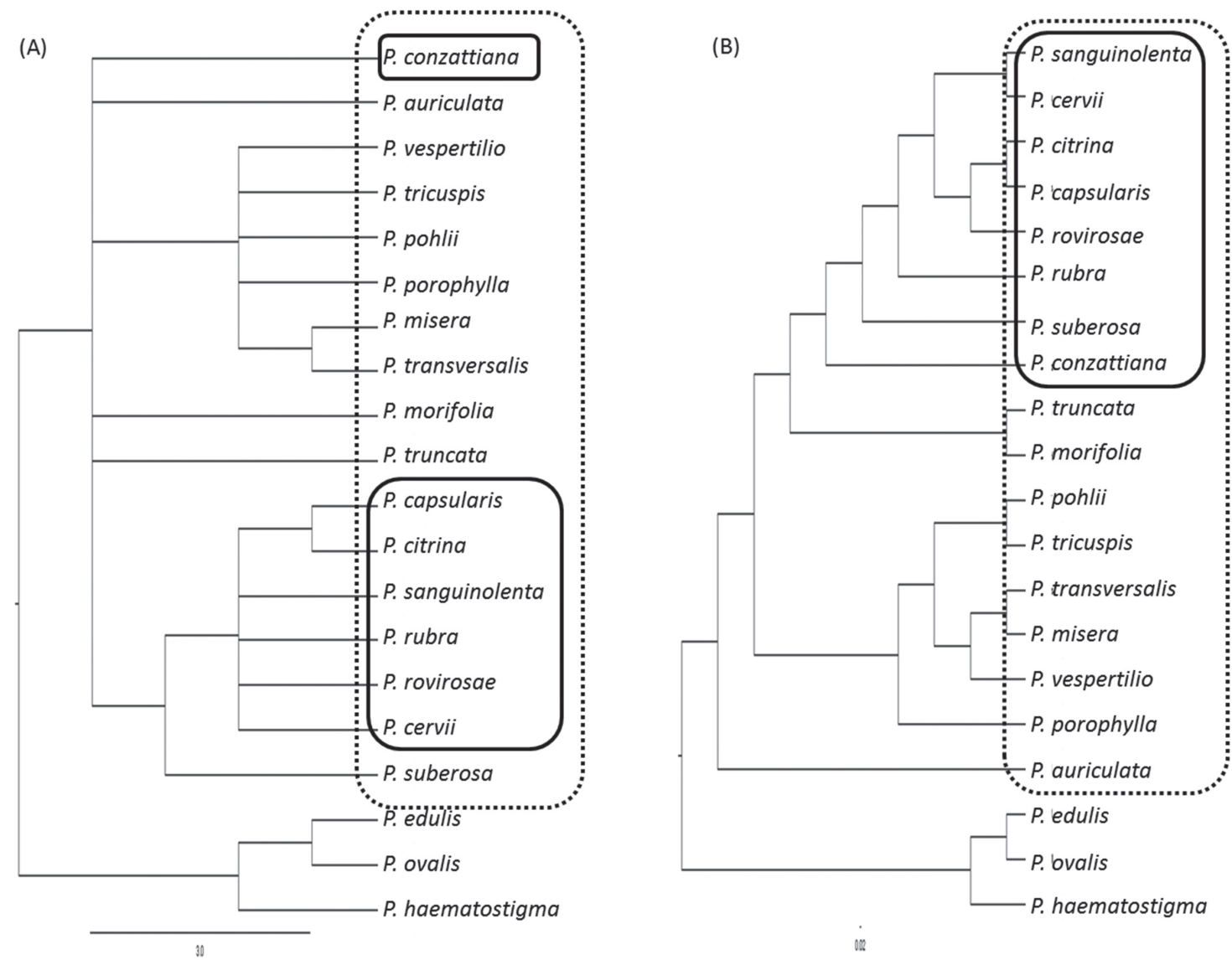

Figure 3. (A) Strict consensus tree of the 69 most parsimonious trees, constructed with the $\operatorname{trn} L-\operatorname{trn} F$ marker. (B) Phylogenetic tree based on the sequences of the $\operatorname{trnL}-\operatorname{trn} F$ region obtained by Bayesian inference.

Continuous line: Passiflora subg. Decaloba supersect. Decaloba sect. Xerogona; dotted line: Passiflora subg. Decaloba.

port. In terms of the ITS marker in the parsimony analysis, P. tenella, which is the species morphologically closest to P. subg. Decaloba supersect. Decaloba sect. Decaloba, appears at the base of the section (Fig. 2). However, in the analysis of Bayesian inference, P. quinquangularis, which is quite similar to and considered by many authors to be a synonym of $P$. capsularis, appeared at the base. These two species ( $P$. tenella and $P$. quinquangularis) appeared to be distinct in terms of this marker. Passiflora capsularis and $P$. sanguinolenta appeared as closely related species, although their flowers are quite distinct and they have different geographic distributions.

The analyses of Passiflora subg. Decaloba supersect. Decaloba sect. Xerogona with the trnL-trnF marker did not show it to be monophyletic in the parsimony analyses (Fig. $3 \mathrm{~A})$. This marker was informative in the separation of the subgenera but was not capable of revealing the relationships of the supersections and sections within each. The tree obtained by the analysis of Bayesian inference with the $\operatorname{trnL}$-trnF marker (Fig. 3B) indicated that the section was monophyletic.

\section{Discussion}

The phylogenetic analyses based on morphological characters indicate that Passiflora morifolia, placed in $P$. subg. Decaloba supersect. Bryonioides, belongs to the clade comprising the species $P$. capsularis, $P$. cervii and $P$. rubra, all of which are within $P$. subg. Decaloba supersect. Decaloba sect. Xerogona; the same was observed in the morphological phylogenetic analyses undertaken by Milward-de-Azevedo (2007) for the component taxa of P. subg. Decaloba occurring in Brazil, due to the synapomorphies demonstrated by these species.

The molecular phylogenetic analyses presented by Muschner et al. (2003), Yockteng \& Nadot (2004), and Hansen et al. (2006) did not support the classifications into supersections, sections, and series. It was seen in the present study that Passiflora subg. Decaloba is monophyletic, and that $P$. subg. Decaloba supersect. Decaloba is monophyletic and divided into two sections: Decaloba and Xerogona. Both of those sections are also monophyletic, corroborating the classifications proposed by Feuillet \& MacDougal (2003) for P. subg. Decaloba; those authors, 
however, found that some of the supersections and series did not form monophyletic groups-a finding that was not confirmed for the specimens analyzed in the present study. Zamberlan (2007) determined P. subg. Decaloba and P. subg. Decaloba supersect. Decaloba to be monophyletic in all of the analyses using ITS markers, as was observed in the present study. However, $P$. subg. Decaloba supersect. Decaloba displayed two groupings; the first included only species of $P$. subg. Decaloba supersect. Decaloba sect. Decaloba, whereas the second comprised species of $P$. subg. Decaloba supersect. Decaloba sections Decaloba and Xerogona and was not monophyletic. In the present work, the sections were considered monophyletic in terms of results of the ITS markers.

In the present study, there were some cases in which our morphological data conflicted with those obtained by phylogenetic analysis, in terms of the divisions into sections within the Passiflora subg. Decaloba supersect. Decaloba, the majority of such analyses have involved only a few species of $P$. subg. Decaloba supersect. Decaloba sect. Xerogona, which would make it more difficult to draw certain distinctions (Muschner et al., 2003; Yockteng \& Nadot, 2004; Zamberlan, 2007).

The phylogenetic analyses developed here, using vegetative, floral, palynological, and fruit morphological data, indicated that Passiflora subg. Decaloba supersect. Decaloba sect. Xerogona is not monophyletic, because it was found to include $P$. morifolia, which belongs to $P$. subg. Decaloba supersect. Bryonioides. Our data do not support the classification proposed by Feuillet \& MacDougal (2003), who constructed the morphological tree. Nevertheless, our results do demonstrate relative congruency with most of the taxonomic affinities inferred for the taxa studied here and allow inferences to be made concerning some of the phylogenetic lineages of the group.

Hansen et al. (2006) noted that none of the published phylogenetic analyses have completely resolved the classification of Passiflora, as the series and sections have not been supported. It is probable that phylogenetic analyses, combined with additional morphological and molecular data, will supply more consistent results and present nonor less-conflicting interpretations of the evolution of the Passiflora taxa. Within this context, new morphological, anatomical, and biogeographic data concerning pollination vectors would be quite useful in examining this highly diversified group within the flora of Brazil.

\section{Acknowledgments}

The authors thank the UNICAMP, CCA/UFES, MN/ UFRJ, UFRGS, ITR/UFRRJ and the Missouri Botanical Garden, for the institutional support provided. We are grateful to Dr. Priscilla Menna Zamberlan and to the biologist Luana Castro, for their assistance in the DNA extraction; to Drs. Jeferson N. Fregonezi and André Olmos Simões, for their assistance with the phylogeny programs; and to Roy Funch, for translating the text. We also thank the staff of the herbaria of the following institutions, for allowing us access to the relevant botanical material: BHCB, ESA, HUEFS, IAC, K, LP, MEXU, PEUFR and VIC. This study received financial support from the Brazilian Conselho Nacional de Desenvolvimento Científico e Tecnológico (CNPq, National Council for Scientific and Technological Development) and from the Fundação de Amparo à Pesquisa do Estado de São Paulo (FAPESP, São Paulo State Research Foundation; Grant no. 2008/56222-3).

\section{References}

Desfeux, C. \& Lejeune, B. 1996. Systematics of Euromediterranean Silene (Caryophyllaceae): evidence from a phylogenetic analysis using ITS sequence. Comptes Rendus: Academie des Sciences 319: 351-358.

Dunn, I.S. \& Blattner, F.R. 1987. Sharons 36 to 40: multi-enzyme, high capacity, recombination deficient replacement vectors with polylinkers and polystuffers. Nucleic Acids Research 15: 2677-2698.

Feuillet, C. \& MacDougal, J.M. 2003. A new infrageneric classification of Passiflora L. (Passifloraceae). Passiflora: The journal \& Newsletter of Passiflora Society International 13(2): 34-38.

Hansen, A.K.; Gilbert, L.E.; Simpson, B.B.; Downie, S.R.; Cervi, A.C. \& Jansen, R.K. 2006. Phylogenetic Relationships and Chromosome Number Evolution in Passiflora. Systematic Botany 31(1): 138-150.

Hansen, A.K.; Escobar, L.K.; Gilbert, L.E. \& Jansen, R.K. 2007. Paternal, Maternal, and Biparental Inheritance of the Chloroplast Genome in Passiflora (Passifloraceae): implications for the phylogenetic studies. American Journal of Botany 94(1):42-46.

Killip, E.P. 1938. The American species of Passifloraceae. Publication Field Museum of Natural History - Botanical Series 19(1-2): 1-613.

MacDougal, J.M. \& Feuillet, C. 2004. Systematics. In: Ulmer, T. \& MacDougal, J.M. (Eds.). Passiflora: Passionflowers of the world. Portland, Oregon: Timber Press.

Milward-de-Azevedo, M.A. 2007. Revisão taxonômica de Passiflora L. subgênero Decaloba (DC.) Rchb. (Passifloraceae) no Brasil. Tese de Doutorado, Universidade Federal do Rio de Janeiro/ Museu Nacional / Programa de Pós-graduação em Ciências Biológicas (Botânica).

Milward-de-Azevedo, M.A.; Gonçalves-Esteves, V. \& Baumgratz, J.F.A. 2004. Palinotaxonomia das espécies de Passiflora L. subg. Decaloba (DC.) Rchb. (Passifloraceae) no Sudeste do Brasil. Revista Brasileira de Botânica 27(4): 655-665.

Milward-de-Azevedo, M.A.; Souza, F.C.; Baumgratz, J.F.A. \& GonçalvesEsteves, V. 2010. Palinotaxonmia de Passiflora L. subg. Decaloba (DC.) Rchb. (Passifloraceae) no Brasil. Acta Botanica Brasilica 24(1): 133-145.

Muschner, V.C.; Lorenz, A.P.; Cervi, A.C.; Bonatto, S.L.; Souza-Chies, T.T.; Salzano, F.M. \& Freitas, L.B. 2003. A First Molecular Phylogenetic Analysis of Passiflora (Passifloraceae). American Journal of Botany 90(8): 1229-1238.

Posada, D. \& Crandall, K.A. 1998. Modeltest: testing the model of DNA substitution. Bioinformatics 14: 817-818.

Presting, D. 1965. Zur Morfhologie der pollenkörner der Passifloraceen. Pollen et Spores 7: 193-247.

Reichenbach, H.G.L. 1828. Conspectus regni vegetabilis. Leipzig, Carl Cnobloch.

Ronquist, F. \& Huelsenbeck, J.P. 2003. MrBayes 3: phylogenetic inference under mixed models. Bioinformatics 19: 1572-1574.

Roy, A.; Frascaria, N.; MacKay, J. \& Bousquet, J. 1992. Segregating random amplified polymorphic DNAs (RAPDs) in Betula alleghaniensisis. Theoretical and Applied Genetics 85: 173-180.

Souza-Chies, T.T.; Yockteng, R. \& Nadot, S. 2005. Systématique moléculaire comparée en France et au Brésil du genre Passiflora L. (Passifloraceae). Cahiers Agricultures 14(2): 209-215. 
Swofford, D, L. 2002. Paup: Phylogenetic usin parsimony (and other methods) 4.0 Beta. Sinauer Associates, Inc. Publishers, Sunderland, Massachussets.

Taberlet, P.; Gielly, L.; Pautou, G. \& Bouvet, J. 1991. Universal primers for amplification of three non-coding regions of chloroplast DNA. Plant Molecular Biology 17: 1105-1109.

Tamura, K.; Peterson, D.; Peterson, N.; Stecher, G.; Nei, M. \& Kumar, S. 2011. MEGA 5: Molecular Evolutionary Genetics Analysis using Maximum Likelihood, Evolutionary Distance, and Maximum Parsimony Methods. Molecular Biology and Evolution 28: 2731-2739.
Thiers, B. [continuously updated]. Index Herbariorum: A global directory of public herbaria and associated staff. New York Botanical Garden's Virtual Herbarium. http://sweetgum.nybg.org/ih/ (Acesso em 24/09/2013).

Zamberlan, P.M. 2007. Filogenia de Passiflora L. (Passifloraceae): questões infra-subgenéricas. Dissertação de Mestrado, Porto Alegre, Universidade Federal do Rio Grande do Sul.

Yockteng, R. \& Nadot, S. 2004. Phylogenetic relationships among Passiflora species based on the glutamine synthetase nuclear gene expressed in chloroplast (ncpGS). Molecular Phylogenetics and Evolution 31: 379-396. 